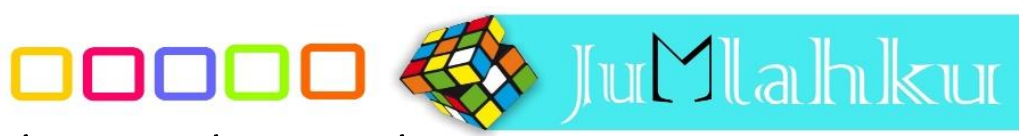

Jurnal Matematika Ilmiah STKIP Muhammadiyah Kuningan $\quad$ E-ISSN : 2654-833X

Vol. 5 No.1 Mei 2019

P-ISSN : 2443-3500

\title{
IMPLEMENTASI PEMBELAJARAN SAINS, TEKNOLOGI, ENGINEERING, DAN MATEMATIKA (STEM) PADA MATERI FUNGSI KUADRAT
}

Sri Endang Supriyatuna)

a) SMPN 4 Metro Lampung sriendangsr@gmail.com

\begin{tabular}{l}
\hline Article Info \\
\hline Kaywords : stem, \\
quadratic function, critical \\
thinking
\end{tabular}

Submited:

Published:
Abstract

The purpose of STEM learning is to improve students' critical thinking skills and problem solving. STEM is a learning approach that integrates the components of science, technology, engeneering and mathematics. in SMP Negeri 4 Metro learning has not been maximal in the use of learning approaches. The ability of students to think critically is also low. It can be seen from the daily assessment that only 5 people achieved the target of a minimum completeness criteria of 75 . Implementation of STEM in quadratic function material can improve the achievement of the minimum completeness criteria target, of the 30 students 22 students have completed. This can be said to increase from the initial conditions of only 5 students. The conclusion of this implementation is that the STEM approach can improve critical thinking skills in quadratic function learning.

\section{Abstrak}

Kata Kunci: stem, Tujuan pembelajaran STEM ini adalah untuk meningkatkan fungsi kuadrat, berpikir kemampuan berpikir kritis siswa dan pemecahan masalah. kritis
STEM adalah pendekatan pembelajaran yang mengintegrasikan komponen-komponen sains, teknologi, engeneering dan matematika. di SMP Negeri 4 Metro pembelajaran yang dilakukan belum maksimal dalam penggunaan pendekatan pembelajaran. Kemampuan siswa berpikir kritis juga tergolong rendah. Terlihat dari penilaian harian hanya 5 orang yang mencapai target kriteria ketuntasan minimal 75. Implementasi STEM pada materi fungsi kuadrat dapat meningkatkan pencapaian target kriteria ketuntasan minimal, dari 30 siswa 22 siswa telah tuntas. Hal ini dapat dikatakan meningkat dari kondisi awal yang hanya 5 siswa. Kesimpulan dari implementasi ini adalah pendekatan STEM dapat meningkatkan kemampuan berpikir kritis siswapada pembelajaran fungsi kuadrat. 


\section{PENDAHULUAN}

Implementasi Kurikulum 2013 dalam pembelajaran berkembang sangat dinamis. Saat ini pembelajaran yang dilakukan oleh guru harus mengacu kepada keterampilan abad ke-21, yaitu yang dikenal dengan 4C (critical thinking, communication, collaboration and creativity and innovation) sehingga keluaran yang dihasilkan mampu menguasai keterampilan dimaksud.

Pada era sekarang dan akan datang siswa harus sanggup mempertahankan dirinya di tengah masyarakat dengan mengembangkan pengetahuan yang diperolehnya. Keterampilan abad ke-21 ini akan membantu siswa untuk mengembangkan potensi dirinya dalam berpikir kritis dengan melihat suatu keadaan di sekitarnya, pentingnya membuat koneksi dan bekerjasama serta kreatif dan inovatif dalam mengambil keputusan untuk memecahkan masalah.

Keterampilan abad ke-21 yang terintegrasi kedalam pembelajaran dapat dirancang melalui desain pembelajaran yang akan digunakakan pada proses pembelajaran di kelas. Perancangan tersebut disesuaikan dengan kompetensi dasar yang telah dijabarkan dalam indikator pencapaian kompetensi sesuai dengan kurikulum yang berlaku.

Dalam pencapaian indikator yang telah dirumuskan, seorang guru dapat mengintegrasikan pengetahuan atau konsep dengan materi pengetahuan atau mapel lain, dapat menggunakan teknologi dan juga dapat mengonstruk produk hasil pembelajaran. Pengintegrasian unsurunsur tersebut dapat menggunakan pembelajaran Sains, Teknologi,Engeneering, dan Matematika (STEM).

Pembelajaran matematika yang dilakukan di SMP Negeri 4 Metro saat ini belum maksimal dalam penggunaan pendekatan pembelajaran, sebagai contoh materi fungsi kuadrat disampaikan dengan cara konvensional atau ceramah dalam menjelaskan topik tersebut. Penyampaian yang hanya menggunakan metode ceramah tidak efektif dalam pencapaian tujuan pembelajaran dan tentunya akan berpengaruh terhadap pencapaian hasil belajar siswa.

Hasil belajar siswa pada kemampuan berpikir kritis tergolong rendah dari 30 siswa di kelas IX E terdapat 5 orang yang mencapai KKM 75 pada penilaian harian persamaan kuadrat.

Saat ini pemerintah terus berusaha menggalakkan pembelajaran STEM khususnya untuk pembelajaran IPA dan Matematika. Tujuan diterapkan pembelajaran STEM tentunya supaya siswa dapat mengintegrasikan pelajaranpelajaran sains, teknologi, dan matematika dalam satu kesatuan yang menjadi dasar siswa untukberlatih berpikir kritis dalam menyelesaikan masalah kehidupan seharihari. Manfaat yang diperoleh siswa tidak hanya terbatas pada saat siswa menempuh pendidikan di SMP atau jenjang sekolah formal saja akan tetapi lebih penting dari itu pada saat siswa telah berada di masyarakat nantinya siswa dapat mengambil manfaat dari pengitegrasian Sains, Teknologi, Engeneering, dan Matematika.

\section{Pembelajaran}

STEM membelajarkan kepada siswa dari penguasaan konsep-konsep setiap topik yang dipadukan dengan prinsip sains, teknologi, engeneering, dan matematika. kesatuan dari pembelajaran STEM ini bertujuan untuk mengembangkan produk, proses dan satu kesatuan sistem yang akan memberi manfaat untuk dirinya dan untuk kehidupan masyarakat luas. 
Berdasarkan uraian tersebut penulis mencoba mengimplementasikan pembelajaran STEM pada proses pembelajaran di SMPN 4 Metro pada materi fungsi kuadrat kelas IX E.

Adapun Tujuan penggunaan pembelajaran STEM ini adalah untuk meningkatkan kemampuan berpikir kritis dan pemecahan masalah siswa.

Kemampuan berpikir kritis adalah kemampuan siswa dalam memahami, menganalisa dan memecahkan masalah serta dapat menggeneralisasi. Artinya seorang siswa dikatakan mampu berpikir kritis dalam menyelesaikan suatu persoalan siswa akan melalui tahapan pemahaman terhadap masalah yang dihadapi, berikutnya melakukan menganalis dengan mengumpulkan datadata yang relevan dari sumber yang terpercaya serta dapat mengambil suatu kesimpulan sebagai keputusan dalam memecahkan masalah.

Kemampuan berpikir kritis menurut Mulyana meliputi kemampuan siswa dalam mengidentifikasi asumsi yang diberikan, merumuskan pokok-pokok permasalahan, menentukan akibat dari suatu yang diambil, mengungkap data, serta mengevaluasi alasan yang relevan dalam penyelesaian suatu masalah (Mulyana, 2009)

Pendapat lain Krulik \& Rudnick dalam (Sumardyono \& Ashari, 2010) mengatakan bahwa berpikir kritis adalah berpikir yang menguji, menghubungkan dan mengevaluasi semua aspek dari situasi masalah, termasuk mengelompokkan, mengorganisasikan, mengingat dan menganalisis informasi. Sumardyono sendiri mengatakan bahwa berpikir kritis itu merupakan kegiatan berpikir yang mendalam, argumentatif-logis dan evaluatif (Sumardyono \& Ashari, 2010).

Berdasarkan uraian di atas secara singkat dapat dikatakan bahwa berpikir kritis dan pemecahan masalah adalah proses berpikir bagaimana siswa mempunyai kemampuan menganalisis informasi menggunakan data yang akurat sehingga dapat mengampil kesimpulan secara tepat dalam pemecahan masalah.

Pembelajaran STEM merupakan pembelajaran yang mengitegrasikan antara konsep sains, teknologi, engeneering, dan matematika yang titik fokusnya pada proses pembelajaran berbasis masalah dalam kehidupan nyata.

Keterampilan yang akan dicapai pada pembelajaran STEM adalah keterampilan yang juga merupakan keterampilan abad 21 yaitu berpikir kritis dan pemecahan masalah, kreatifitas, kolaborasi, komunikasi, dan juga penelitian.

Komponen STEM terdiri dari sains yaitu kajian tentang fenomena alam yang melibatkan observasi dan pengukuran, sebagai wahana untuk menjelaskan secara obyektif alam yang selalu berubah; Teknologi adalah tentang inovasi-inovasi manusia yang digunakan untuk memodifikasi alam agar memenuhi kebutuhan dan keinginan manusia, sehingga membuat kehidupan lebih baik dan lebih aman; Engeneering adalah pengetahuan dan keterampilan untuk memperoleh dan mengaplikasikan pengetahuan ilmiah, ekonomi, sosial, serta praktis untuk mendesain dan mengkonstruksi mesin, peralatan, sistem, material, dan proses yang bermanfaat bagi manusia secara ekonomis dan ramah lingkungan; Selanjutnya, matematika adalah ilmu tentang pola-pola dan hubungan-hubungan, dan menyediakan bahasa bagi teknologi, sains, dan engeneering (Firman, 2015)

Integrasi STEM merupakan kesempatan emas dalam memeperoleh pengalaman belajar siswa dalam dunia nyata (Wang, Moore, Roehrig, \& Park, 
2011) Integrasi pendidikan STEM adalah sebagai pendekatan yang dalam pembelajaran dapat mengekplorasi antara dua subjek pada lingkup STEM atau antara subjek STEM dengan bidang lain (Sanders, 2008). Artinya pada pendekatan STEM pada pembelajaran dapat diintegrasikan antara satu atau lebih bidang yang termasuk dalam STEM yaitu sains dengan teknologi, atau sains dengan matematika atau dapat terintegrasi dari ketiga bidang tersebut juga dapat dikembangkan ke mata pelajaran lain sebagai pendukung seperti Ilmu Sosial, Seni atau Bahasa (SEAMEO, 2018a).

Karakteristik pembelajaran STEM adalah selain terintegrasi antara sains, teknologi, engeneering dan matematika, STEM merupakan pembelajaran berbasis proyek, dan mengembangkan keterampilan serta kreatifitas siswa. Mengembangkan sikap kolaboratif sesama siswa.

Diharapkan integrasi STEM dalam pembelajaran dapat diterapkan seperti model integrasi pembelajaran yang disebut sebagai Authentic Integration, yang terdiri dari knowledge development, synthesis and application; focused inquiry resulting in higher order learning; application to realworld scenarios; and rich tasks (SEAMEO, 2018b). Artinya bahwa integrasi STEM dalam pembelajaran terdiri atas pengembangan konsep ilmu pengetahuan, kemampuan memadukan unsur-unsur baru dan menerapkan untuk menyelesaikan masalah nyata, berpusat pada hasil penemuan dalam pembelajaran tingkat tinggi dan kaya akan pertanyaan.

Secara ringkas dapat dikatakan bahwa pembelajaran STEM merupakan perpaduan yang saling mendukung antara konsep sains, penggunaan teknologi, engeneering dan konsep matematika. Perpaduan STEM membuat siswa berpikir kritis dan kreatif dalam menyelesaikan permasalahan yang diperoleh dalam dunia nyata sehingga solusinya tersebut berdampak positif dan bermanfaat untuk dirinya dan masyarakat.

\section{METODE}

Rancangan pembelajaran STEM ini dikhususkan pada Kompetensi Dasar 4.4 Menyajikan dan menyelesaikan masalah kontekstual dengan menggunakan sifat-sifat fungsi kuadrat. Dengan materi pembelajaran Fungsi Kuadrat, materi ini diberikan di kelas IX semester ganjil.Indikator pencapaian kompetensi yaitu siswa mampu menginterpretasikan grafik fungsi kuadrat serta menggunakan fungsi kuadrat untuk menyelesaikan masalah.

Metode yangdigunakan dalam pembelajaran STEM adalah diskusi, proyek dan pemberian tugas. Menggunakan model pembelajaran berbasis proyek. Penerapan pembelajaran basis STEM ini dilakukan dalam tiga pertemuan.

Pada pertemuan pertama siswa akan membuat desain produk dan membuat produk sesuai rancangan dan melakukan uji coba. Pertemuan kedua siswa menginterpretasikan kurva hasil pengamatan sebelumnya dan dihubungkan dengan simulasi aplikasi geogebra tentang konsep fungsi kuadrat. Terakhir pada pertemuan ketiga siswa melakukan tes kemampuan berpikir kritis.

Rancangan pembelajaran STEM menurut (Setiadi, 2018) terdiri dari identifikasi masalah; menggabungkan materi dan ide untuk menemukan cara menyelesaikan masalah; merancang dan menguji produk apakah produk tersebut dapat menyelesaikan masalah; evaluasi keberhasilannya dilihat dari hasil tes, analisis dan interpretasi data; tandai hal-hal yang dapat digunakan untuk memperbaiki produk untuk lebih baik; dan komunikasikan ide-ide inovasi tersebut. 
Berdasarkan tahapan di atas rancangan pembelajaran STEM pada materi fungsi kuadrat dimulai dari menganalisis materi terkait STEM.

Materi yang berkaitan dengan sains adalah tekanan. Teknologi yang digunakan adalah aplikasi geogebra. Proses engeneering yang dilakukan adalah mendesain produk air mancur. Matematika yang digunakan yaitu tentang menginterpretasikan grafik fungsi kuadrat.

Selanjutnya melakukan tahapan pembelajaran dengan STEM berbasis proyek yang terdiri dari kegiatan pendahuluan, kegiatan inti dan penutup. Pada kegiatan inti dilakukan tahapan pembelajaran yaitu identifikasi masalah sesuai materi pembelajaran; selanjutnya siswa mendiskusikan penyelesaian masalah; menentukan dan mendesain produk yang akan digunakan untuk memecahkan masalah; uji coba produk yang dihasilkan; selanjutnya melakukan perbaikan produk untuk lebih baik lagi dan tahapan terakhir adalah mempresentasikan hasil diskusi.

Alat ukur yang digunakan yaitu instrumen penilaian produk yang dihasilkan dan tes untuk mengetahui kemampuan berpikir kritis siswa. Penilaian produk menggunakan instrumen penilaian proyek, dilakukan dari proses perencanaan, proses pengerjaan tugas sampai hasil akhir proyek. (Kemdikbud, 2014)

Indikator keberhasilan terhadap produk yang dihasilkan adalah minimal mendapat nilai 75 dari semua aspek yang dinilai berdasarkan instrumen yang digunakan sebagai acuan penilaian dan hasil tes siswa memenuhi kriteria yang ditentukan yaitu 75 .

Kriteria penilaian proyek dan hasil tes seperti pada tabel 1 berikut. Tabel 1. Kriteria Penilaian Proyek dan Hasil Tes

\begin{tabular}{|c|c|c|}
\hline Skor $(\mathrm{X})$ & Kriteria & Keterangan \\
\hline $\begin{array}{c}90 \leq x \leq \\
100\end{array}$ & A & Amat Baik \\
\hline $\begin{array}{c}82 \leq x \leq 89 \\
75 \leq x \leq 81\end{array}$ & B & Baik \\
\hline$<75$ & D & Cukup \\
\hline
\end{tabular}

(kemdikbud, 2016)

\section{HASIL DAN PEMBAHASAN}

Hasil penerapan pembelajaran STEM pada materi Fungsi Kuadrat di awali dengan kegiatan pendahuluan yaitu menyampaikan tujuan pembelajaran; melakukan apersepsi dan motivasi.

Pada kegiatan inti siswa diberikan masalah untuk diselesaikan yaitu membuat produk air mancur dengan menggunakan botol bekas air mineral dan selang. Siswa bekerja secara kelompok dan berdiskusi membuat desain.Dan setiap kelompok diberikan 3 buah botol bekas air mineral $600 \mathrm{ml}$. Siswa mendesain produk air mancur dengan cara meletakkan selang pada tutup botol yang dilubangi seluas penampang selang lalu di lem.

Selanjutnya pada bagian bawah botol diberi satu lubang untuk botol 1, dua lubang untuk botol 2 dan tiga lubang untuk botol 3 dengan ukuran diameter kurang lebih $0,3 \mathrm{~cm}$. Selang dihubungkan dengan airator yang dimasukkan ke dalam ember berisi air. Airator dapat digantikan dengan menghubungkan selang langsung ke kran air.

Langkah berikutnya siswa diminta melakukan uji coba produk dan melakukan pengamatan, serta mencatat hasil pengamatan. Pada uji coba yang pertama menggunakan botol 1, uji coba kedua menggunakan botol 2 dan uji coba selanjutnya menggunakan botol 3 .

Secara keseluruhan hasil pengamatan setiap kelompok pada intinya sama. Pada botol 1 pancaran air akan jatuh lebih jauh dibandingkan air yang jatuh pada botol 2 dan 3 . Botol tiga dengan lubang lebih banyak jarak pancar air lebih dekat dari titik pancang botol. Tekanan dan

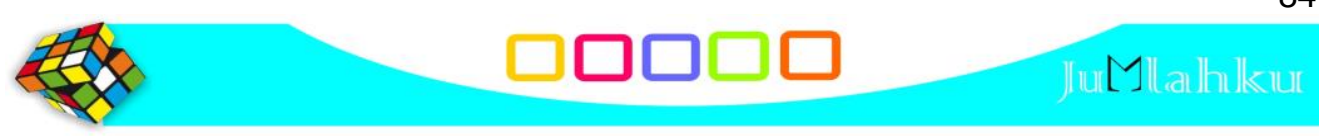


lubang yang terdapat pada botol memengaruhi panjang lintasan air. Semakin besar tekanannya maka semakin jauh lintasannya sebaliknya semakin kecil tekanannya maka semakin dekat juga lintasannya. Secara keseluruhan siswa menyimpulkan bahwa jarak lintasan yang terjadi karena dipengaruhi oleh tekanan cat cair.

Beberapa produk yang dihasilkan masih belum sempurna seperti bagian lubang yang dibuat tidak sama. Tahapan selanjutnya melakukan perbaikan produk untuk lebih baik dan terakhir adalah mempresentasikan hasil diskusi dan membuat laporan.

Pembelajaran berikutnya yaitu menganalisis hasil pengamatan yang diperoleh dari percobaan air mancur.

Hasil pengamatan siswa dapat divisualisasikan dengan menggunakan sketsa grafik fungsi kuadrat, yaitu sebagai berikut.

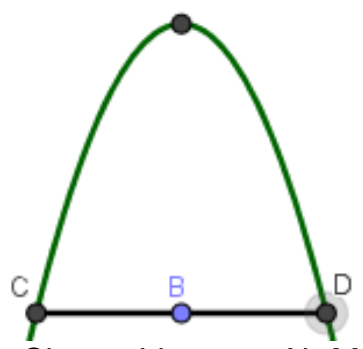

Gambar 1. Sketsa Lintasan Air Mancur

Titik C adalah titik awal pada permulaan air mancur pada botol, titik $D$ merupakan batas akhir pancaran air mancur. Dan titik B adalah titik tengah antara CD. Selanjutnya siswa membuat garis koordinat tepat pada titik $C$ sebagai pusat sumbu atau $(0,0)$ dan mengukur berapa panjang jarak dari $C D$, dan menentukan titik tengahnya. Adapun bentuk gambarnya sebagai berikut.

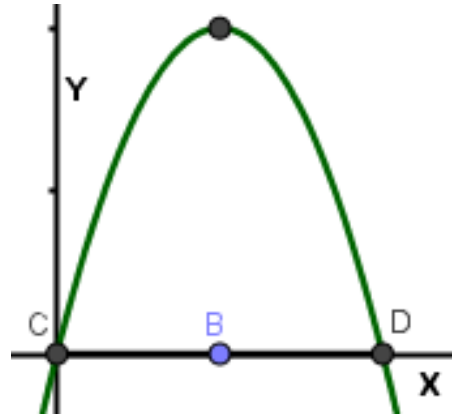

Gambar 2. Sketsa Grafik pada Sumbu Koordinat

Dalam pengukurannya siswa menentukan titik $D$ dengan ukuran $12 \mathrm{~cm}$, artinya grafik melalui berjarak $12 \mathrm{~cm}$ atau $(12,0)$ dari titik awal pancar air $(0,0)$. Siswa diarahkan untuk mengukur titik $B$ dan mengukur tinggi puncak lintasan dari titik $B$.

Siswa diminta mengeksplorasi informasi tentang data yang terdapat dalam fungsi kuadrat. Sehingga berdasarkan sketsa grafik fungsi kuadrat ini siswa dapat menentukan titik potong grafik terhadap sumbu $X$ yaitu $(0,0)$ dan $(12,0)$, sumbu simetri yaitu titik tengah antara CD sehingga dapat menentukan persamaan sumbu simetrinya adalah 6 . Titik puncak grafik diperoleh dengan cara pengukuran dengan menggunakan alat ukur. Dalam hal ini tinggi yang diperoleh siswa adalah 10 $\mathrm{cm}$, artinya bahwa tinggi maksimum grafik adalah $10 \mathrm{~cm}$. Sehingga titik balik maksimum grafik adalah $(6,10)$.

Hasil pengamatan yang berupa lintasan berbentuk parabola dikaitkan dengan konsep matematika dengan menggunakan aplikasi geogebra. Dalam hal ini guru membuat simulasi grafik fungsi kuadrat, dengan bentuk umum fungsi kuadrat $f(x)=a x^{2}+b x+c$ dan siswa melakukan pengamatan.

Selain melakukan simulasi grafik fungsi kuadrat yang identik dengan lintasan air mancur dikembangkan pula grafik fungsi kuadrat yang lain, yaitu grafik yang terbuka ke bawah.

Dari hasil pengamatan siswa dapat menginterpretasikan grafik fungsi kuadarat tersebut. Siswa dapat menyebutkan sifat grafik yang terbuka ke bawah akan mempunyai titik balik maksimum, jika terbuka ke atas memiliki titik balik 
minimum. Grafik fungsi kuadrat akan terbuka ke bawah apabila koefisien $a<0$ dan akan terbuka ke atas apabila koefisien $a>0$.

Dari grafik juga siswa dapat menentukan titik potong terhadap sumbu $\mathrm{X}$, titik potong terhadap sumbu $\mathrm{Y}$, siswa juga dapat menentukan sumbu simetri serta titik balik fungsi. Pada tahap akhir siswa dapat menentukan persamaan fungsi kuadrat dengan bimbingan.

Berdasarkan uraian di atas dapat dikatakan bahwa kegiatan yang dilakukan siswa telah mengintegrasikan komponenkomponen STEM. Komponen sains terlihat ada hubungannya produk air mancur yang dihasilkan denga sais yaitu tentang tekanan zat cair.

Komponen teknologi terlihat pada saat hasil pengamatan lintasan dikaitkan dan divisualisasikan dengan menggunakan aplikasi geogebra.

Komponen engeneering terlihat dalam proses merancang produk air mancur dengan tiga buah botol bekas air mineral. Proses ini memberikan siswa untuk berpikir dalam penyelesaian masalah yang dihadapi.

Siswa akan dapat memilih produk sesuai yang diinginkan. Artinya saat siswa menginginkan pembuatan produk yang menghasilkan jarak lintasan pancar air yang jauh maka siswa dapat memilih produk seperti pada botol satu. Siswa juga akan dapat memilih dan berpikir kreatif jika akan membuat air mancur yang jarak pancarnya tidak jauh maka siswa akan dapat memperkirakan jumlah lubang yang terdapat pada botol.

Komponen matematika terdapat pada konsep fungsi kuadrat. Pemahaman terhadap grafik dan interpretasinya.

Hasil produk siswa secara keseluruhan dapat dikatakan baik, hasil tersebut dapat dilihat pada tabel berikut.

Tabel 2. Skor Produk Kelompok

\begin{tabular}{|c|c|c|}
\hline Kelompok & Skor & kriteria \\
\hline 1 & 7 & Cukup \\
\hline 2 & 7 & Cukup \\
\hline 3 & 8 & Baik \\
\hline
\end{tabular}

\begin{tabular}{|l|l|l|}
\hline 4 & 7 & Cukup \\
\hline 5 & 8 & Cukup \\
\hline
\end{tabular}

Skor maksimal dari tiga aspek yang dinilai adalah 9. Kelompok 3 dan kelompok 5 memperoleh skor 8 sama dengan nilai 89 dengan kriteria baik. Kelompok ini telah memenuhi ketuntasan minimal yang telah ditentukan.

Sementara itu tiga kelompok lainnya memperoleh skor 7 atau sama dengan nilai 78. Kelompok ini secara pencapaian ketuntasan minimal telah tuntas, hanya saja kriteria masih tergolong cukup. Secara keseluruhan produk yang dihasilkan oleh seluruh kelompok telah memenuhi kriteria ketuntasan minimal dari penilaian keterampilan.

Pembelajaran berikutnya yaitu mengukur kemampuan berpikir kritis siswa. Alat ukur yang digunakan adalah instrumen tes. Tes terdiri dari 3 soal esai. Tes hasil kemampuan berpikir kritis dilakukan pada akhir pembelajaran kompetensi dasar yaitu pada pertemuan ketiga. Siswa diberikan tes kemampuan berpikir kritis. Sebanyak 30 siswa mengikuti tes ini.

Hasil tes yang diperoleh adalah 22 siswa mencapai nilai lebih dari atau sama dengan 75 dan 8 siswa lainnya masih di bawah standar ketuntasan. Peningkatan diukur dari data awal terkait dengan penilaian harian pada materi persamaan kuadrat.

\section{PENUTUP}

\section{Simpulan}

Simpulan dari penulisan ini adalah penggunaan pembelajaran STEM dapat meningkatkan kemampuan berpikir kritis dan pemecahan masalah siswa.

\section{Saran}

Saran untuk guru matematika dan IPA bahwa pembelejaran STEM dapat digunakan untuk meningkatkan kemampuan berpikir kritis sehingga dapat diterapkan pada pembelajaran di kelas. Selain itu artikel ini dapat digunakan sebagai acuan dalam pembelajaran STEM. 


\section{DAFTAR PUSTAKA}

Firman, H. (2015). Pendidikan sains berbasis STEM: Konsep, pengembangan, dan peranan riset pascasarjana. In Disampaikan pada Seminar Nasional Pendidikan IPA dan PLKH Universitas Pakuan, Agustus.

kemdikbud. (2016). Panduan Penilaian. Jakarta: Kemdikbud.

Mulyana, T. (2009). Pembelajaran analitik sintetik untuk meningkatkan kemampuan berpikir kritis dan kreatif matematika siswa SMA.

Educationist, 3(1), 43-48.

Sanders, M. E. (2008). Stem, stem education, stemmania.

SEAMEO. (2018a). Eksplorasi Aktivitas STEM untuk Siswa Sekolah
Menengah Atas. Yogyakarta: Qithep In Mathematics.

SEAMEO. (2018b). Unit Pembelajaran pada Aktivitas STEM. Yogyakarta: Qithep In Mathematics.

Setiadi, H. (2018). framework Penyusunan Soal Berbasis STEM (pp. 1-52). Bandung: Qitep In Science.

Sumardyono, \& Ashari, S. (2010). Kajian Kritis dalam Pembelajaran di SD. Yogyakarta: P4TK Matematika.

Wang, H.-H., Moore, T. J., Roehrig, G. H., \& Park, M. S. (2011). STEM integration: Teacher perceptions and practice. Journal of Pre-College Engineering Education Research ( $\mathrm{J}$ PEER), 1(2), 2. 